\title{
ON THE PRESENCE AND ABSENCE OF COCOONS AMONG ANTS, THE NEST-SPINNING HABITS OF THE LARV $Æ$ AND THE SIGNIFICANCE OF THE BLACK COCOONS AMONG CERTAIN AUSTRALIAN SPECIES.**
}

By William Morton Wheeler.

It has long been known that in three of the five subfamilies of ants, the Dorylinæ, Myrmicinæ and Dolichoderinæ, the larvæ spin no cocoons before pupation, and therefore remain nude, or uncovered in this instar. There is apparently no exception to this rule in these three subfamilies. The cocoon is present, so far as known, in all members of the subfamily Ponerinæ, with the single exception of a small African ant, Discothyrea oculata, and is lacking among the Camponotinæ only in a few whole genera and a few sporadic species of other genera. The pupæ of the genera Prenolepis and Ecophylla are naked, and in some species of Formica (e. g. the circumpolar $F$. fusca L. and its vars. subsericea Say, neorufibarbis Emery, etc. in North America) one often finds only naked or both naked and cocooned pupæ in the same nest. This is also the case, though much more rarely, in certain species of Lasius. A few species of the large paleotropical genus Polyrhachis also lack the cocoon in the pupal stage, as I shall show in the sequel.

These facts naturally suggest the inference that the cocoon, inherited from the ancient wasp-like ancestors of the ants, has been retained in the most primitive subfamily, the Ponerinæ, from which, by common agreement, the four other subfamilies are descended, and that it has been lost in three and is tending to disappear in the fourth of these. Certain authors, indeed, seem to believe that the disappearance has been comparatively recent in the phylogenetic history of the Formicidæ. In this sense I interpret the following remarks of Janet (1896): "We are no doubt witnessing in the ants the disappearance of this protective envelope, which is rendered unnecessary by the incessant care devoted to the progeny. From the point of view of the evolution of instinct, it is interesting to note that

\footnotetext{
*Contributions from the Entomological Laboratory of the Bussey Institution, Harvard University, No. 95.
} 
the disappearance is not accomplished gradually, by successive attenuation or evanescence of the cocoon, but suddenly, so to speak, since larvæ that are similar and give rise to similar adults, make an absolutely perfect cocoon, which shows no signs of reduction, or make none at all. This may be cited as an example of the sudden changes that may supervene in the habits of an animal. It illustrates the conclusions embodied in a communication made by my brother, M. Armand Janet, to the Leyden Congress. These conclusions, deduced from considerations of rational mechanics applied to the problem of the species regarded as a position of equilibrium, tend to show that the differences obtaining between a form and its derivatives are more probably produced by rather sudden saltations than by insensible and continuous variations."

In other words, Janet regards the disappearance of the cocoon in ants as due to what we now call "mutation," and intimates that in certain species the process is still going on. I am willing to grant the partial truth of this contention, but I have recently found evidence to prove that, far from being a recent loss, the disappearance of the cocoon, in certain genera of ants at least, had already taken place not less than two million years ago. Among the Dolichoderinæ of the Baltic amber, which is of Lower Oligocene Tertiary age, I find the pupæ of certain species already lacking the cocoon, and this structure is likewise absent in a species belonging to the Camponotine genus Prenolepis ( $P$. henschei Mayr) in the same formation (1914). Facts like these are calculated to impress us with the immense antiquity of many apparantly trivial structures and to convince us that we cannot dispense, even in these days of experimental biology, with a certain amount of "phylogenetic speculation."

What has led to the disappearance of the cocoon in the Myrmicinæ, Dorylinæ and Dolichoderinæ and in a few genera and sporadic species of other genera among the Camponotinæ? This question no doubt admits of several answers. Janet, as we have seen, believes that the cocoon became superfluous and disappeared because it was replaced by the fostering care and protection of the workers of the colony. But if this is the case, why do the most formidable of all ants, the Australian "bull-dogs" (Myrmecia), retain the cocoon and such feeble 
species as many Dolichoderinæ (Leptomyrmex, Tapinoma, Bothriomyrmex, etc.) dispense with it? And why is it retained by the fierce Formica sanguinea and so often absent in F. fusca and its varieties, the gentle slaves of this ant? That the presence of the cocoon is primitive and its suppression a secondary phenomenon must be granted, and it is evident.that the loss of the structure must be due primarily either to a loss of the spinning instincts on the part of the larvæ or to a change in the instinct of the adult worker ants in so far as these instincts are concerned with the treatment of the larvæ. The latter change might conceivably consist in a lapse of the habit of burying the mature larvæ in the earth or in covering them with particles of earth or refuse, since ant larvæ are known to be quite unable to spin their elliptical cocoons unless thus temporarily enveloped with foreign particles to which they can attach the thread from their sericteries.

The frequent appearance of nude pupæ in the typical Formica fusca and some of its varieties may be attributed to the fact that these forms are peculiar to high altitudes and latitudes, where the reproductive season of the colony is considerably abbreviated. The omission of the cocoon would seem, therefore, to be due to "tachygenesis," or acceleration of ontogenetic development, since the spinning of this envelope not only requires a number of hours and an expenditure of energy and material, and therefore delays pupation, but the envelope itself is probably in some degree a nonconductor and would therefore tend to prolong development under circumstances that demand a very rapid utilization of the sun's heat by the pupa if it is to reach maturity at the proper time. The loss of the pupal covering in the Myrmicinæ, Dolichoderinæ and Dorylinæ in the remote past may have been due to the same or similar causes.

That the behavior of the workers of the ant-colony in some species does actually influence the spinning activities of the larvæ is indicated by the following facts. In the great majority of larvæ which use their spinning glands, these organs are called into activity only at the end of the larval stage and for the purpose of making the cocoon, but within recent years several observers have called attention to a series of tropical ants belonging to at least three very different genera of Camponotinæ, 
namely, Ecophylla, Camponotus and Polyrhachis, which have the extraordinary habit of using their larvæ for the purpose of spinning silken nests for the colony. This habit has been observed by Ridley (1890, 1894), Hammond (Green 1900), Green (1900, 1903), Doflein (1905, 1906) and Bugnion (1909) in the red tree-ant of India (Ecophylla smaragdina), by SavilleKent (1891, 1897), Dodd (1902), O'Brien (1910) and myself in the green tree-ant of Northeastern Australia (CE. smaragdina var. virescens), and by Chun (1903) in CE. longinodis of the Kamerun. More recently Goeldi (Forel 1905) has observed this habit in a South American Camponotus (C. [Myrmobrachys] senex F. Smith) and Jacobson (Forel 1911, Wasmann 1905) and Karawaiew (1906) have observed the same behavior in several species of Polyrhachis. Green (1903) found that although the larval $E$. smaragdina is employed as a shuttle in spinning the silken portions of the nest, it does not spin a cocoon for itself, but forms a naked pupa. He says: "This seems to be explicable only on the theory that the silk that would normally be employed in the construction of the cocoon is systematically converted to the purpose of nest building, and that the larvæ have consequently lost the habit of cocoon formation." This was a natural view to take, especially as Green (1900) believed that only full grown larvæ were used in spinning the nest. The conditions, however, are more complicated than they appeared to Green, since later observers have shown that Ecophylla uses only its very young larvæ in nidification, and that cocoons are actually formed by the larvæ of many of the nest-spinning species of Polyrhachis. As I have lately had an opportunity to study the nest-spinning habits of $E$. virescens in Australia and am able to record a few new facts concerning an Australian Polyrhachis and a Central American Camponotus not hitherto known to produce silken nests, I take this occasion to transcribe a few observations from my note-books.

I find the earliest mention of the green tree ant in Capt. Cook's narrative of his first voyage. He landed May 23, 1770, somewhere in the neighborhood of the present Townsville, on the coast of Northern Queensland, "within the point of a bay, which led into a large lagoon, by the sides of which grows the true mangrove. There," he says, "were many nests of a singular kind of ant, as green as grass, in the branches of these 
mangroves," etc. This passage came to my mind when I landed for an hour at Lucinda Point, north of Townsville, and found the nests of the green ants on the mangroves just as they had been observed by Capt. Cook. Later, while sojourning for a few weeks at Cairns on the Cape York Peninsula, I had an opportunity to become well acquainted with this ant. In the outskirts of this pretty town it may be found on all kinds of trees and bushes, building its nests in the leaves from a few feet above the ground to the inaccessible branches of the highest Melaleuca trees. The thorax and legs of the slender workers of $C$. virescens are brownish straw yellow, the gaster bright green and the head tinged with the same color. Usually it prefers trees with rather thin, flexible, lanceolate leaves a few inches in length, which may be easily drawn together, but occasionally it makes its nests even on wattles with thick phyllodes. The nests are more or less elliptical and vary in size from a few inches to a foot or more in length and to eight inches in diameter. Smaller nests or tents, for the accomodation of Homoptera, may consist of only a few leaves, but larger ones often take up nearly all the leaves on a small branch or on two neighboring branches. Some of the nests are very beautifully constructed, the leaves being drawn together and plaited in such a manner that the superficial layer forms a smooth, mosaic covering. The interior of the nest consists of the enclosed, more or less crowded or curled leaves.

On several successive days I endeavored to observe the spinning habits of virescens by tearing small rents in the nests and waiting to see the ants repair them. Occasionally I saw some of the workers line up on the outside of the nest as described by previous observers, and draw the leaves on each side of the rent together, but I failed to see the spinning of the silken film across the gap. On October 16th, however, I came upon a remarkable nest in process of construction. It was 3 o'clock in the afternoon and the nest hung in the shade about 8 feet from the ground on a wattle branch, which I partially broke in order to bring the structure to a level with my eyes, where I could watch it without disturbing the ants. It was very large and somewhat flattened, about 14 inches long, 7 inches broad and 4 inches thick. The leaves (or rather phyllodes) had evidently just been brought together, as the 
whole outer surface was covered with hundreds of ants, all forming living sutures along the contiguous edges of the leaves. In most cases these sutures consisted of a single row of ants, side by side, with their mandibles grasping the edge of one leaf and the large claws of all their backwardly directed feet fixed into the edge of another adjacent leaf. Where the gap between the leaves of the outer layer was too wide to be spanned by single ants, there were parallel chains each consisting of two to seven ants, each ant holding the petiole of the ant in front in its mandibles and being grasped in the same place by the ant behind, exactly as described by Dodd for $E$. virescens and figured by Bugnion for the true smaragdina of Ceylon.*

The longer chains often ran diagonally across the shorter. The nest presented a startling appearance, with these hundreds of green ants immovably fixed on its outer surface and accentuating the more or less contiguous borders of the leaves. Then I noticed that there was great activity on the branch leading to the nest. Files of workers were running along it to and from the nest and could be traced to two much smaller nests consisting of dead leaves on an adjacent tree about 30 feet away. The colony had evidently outgrown these nests and was in the act of building the more commodious domicile I had been observing. Closer inspection showed that about one in a dozen of the workers coming to the new nest was carrying in its mandibles a minute milk-white larva, and as the larvæ accumulated, I was able to observe all the stages in the spinning of the silken film. Many of the ants worked from the inside, but quite a number stationed themselves on the outside of the nest where I could see them very clearly under my pocket lens, while they moved their larvæ back and forth as living shuttles from the edge of one leaf to that of another, pausing only while the larvæ attached their extremely delicate threads to the surface of the leaf. A single ant would sometimes work in the same spot for 10 to 20 minutes, moving its larva so nearly through the same arc as to produce a stout silken band or cord from the

*The question naturally suggests itself as to whether the greatly elongated petiole of Ecophylla is not an adaptation to this peculiar use. I have recently (1914) called attention to the fact that the fossil species of Ecophylla (brevinodis Wheeler and brischkei Mayr of the Baltic amber and sicula Emery of the Sicilian amber) have a shorter petiole than the recent smaragdina. This indicates, perhaps, that the species of the Lower Oligocene and Miocene had not yet acquired or were merely in process of acquiring the habit of forming chain sutures. 
individually invisible threads. In other cases the movements were more varied so that the threads crossed and recrossed one another till they gradually formed a delicate film or tissue. Only very young larvæ, about $2-3 \mathrm{~mm}$. in length, were employed. The nest was watched till darkness came on. There was no movement on the part of the ants that were warping and holding the stiff leaves in place, and the weaving workers were still toiling when I was compelled to return to my hotel for the night.

At nine o'clock on the following morning, when I hastened to the nest, I found few ants on its outer surface and none holding the leaves in position, for during the night the ants had filled out all the narrow spaces with white silken tissue. This must have represented an enormous amount of labor on the part of the workers and a corresponding expenditure of material on the part of the larvæ. On gently opening a few of the sutures so that I could look into the nest, I found that the chains of workers were now stationed on the inside warping the leaves while the larvæ were being employed in spinning them together to form chambers. The spaces between the leaves were full of ants and brood as the whole colony had now moved into the new quarters. The day was growing warm and the leaves of the nest were beginning to wilt as the result of my breaking the branch on the previous day.

At three o'clock I again visited the nest and was startled by the great change which it had undergone. The heat of the sun had dried the thick phyllodes of the wattle branch till they had curled and ruptured the silken tissues, so that the whole nest was disintegrated, so to speak, and had been entirely deserted by the ants. Under natural conditions the leaves of the nests also die and dry up after the ants have been living in them for some time, but so gradually as not to break the silken sutures.

When one realizes the great expenditure of labor and valuable material in constructing one of these nests, one is not surprised to find that the ants are exceedingly aggressive in defending their property. When a nest is broken open or even roughly shaken the ants rush out and gather in great numbers at one or a few points on its outer surface where they assume a peculiar threatening attitude. Doflein has given a figure of this attitude in $C$. smaragdina, but his figure is not altogether 
accurate, at least for the var. virescens. This ant rises on its middle and hind legs, so that they are nearly straight, the fore pair are thrust out into the air and often waved about as if to grasp the intruder and the mandibles are opened as widely as possible. A slight shock to the nest when the workers are thus congregated will precipitate the whole mass of them over one's clothes and head. Then one may notice a peculiar method of behavior which is evidently merely a modification of the posture assumed by the ants when they are holding the leaves together during the construction of the nest. After digging the claws of their backwardly directed legs into one's skin, they seize the skin in front of them with their mandibles and begin to pull slowly and steadily. This produces a peculiar sensation as if the skin were tightly bound with cords. It is especially marked when a row of ants seizes the skin of one's neck with the mandibles and fastens the claws into the edge of one's collar.

I was unable to study the founding of the colonies of virescens as the ants had not yet produced their annual generation of sexual individuals at the time of my visit to Queensland, but Mr. F. P. Dodd informs me that the huge, recently fecundated queen, after cutting off her wings, takes up her abode in a curled leaf. In the course of a few days she lays, a batch of eggs and when they hatch she employs the young larvæ in spinning enough silk to bind the edges of the leaf together. A figure (Fig. 135) and a few brief notes published by MaxwellLefroy and Howlett in their work on Indian insect-life (1909) suggest that the queen of the typical smaragdina founds her colony in the same manner.

The large genus Polyrhachis has been recently divided into several subgenera. I have found that the numerous Australian species of three of these, Campomyrma, Hagiomyrma and Chariomyrma, all nest in the ground under stones or pieces of wood, except Hagiomyrma semiaurata, which nests in great logs. The small, shining black species, with peculiarly arched thorax, now referred to the subgenus Cyrtomyrma, however, inhabit silken nests attached to the leaves of trees. This is true, at least, of the Australian C. levior Roger and its var. yorkana Forel, which are merely forms of the Indomalayan rastellata Latreille. I found the nests of lavior to be of small size and usually built on thick, broadly lanceolate leaves such as those 
of the mangrove and a species of Wurmia. Sometimes two leaves have their edges spun together with a silken tissue, or a silken bladder with a short tubular entrance is constructed on the lower surface of a single leaf. The outer surface of the silk is thickly covered with minute vegetable particles. There are only 25 to 50 ants in a colony and the pupæ are always naked. This is interesting, because all the other nest-spinning species of Polyrhachis, of which at least 20 are mentioned in the literature, are described as having the pupæ enclosed in cocoons just as they are in the species that nest in the ground or in logs. It is evident, therefore, that the larvæ of the subgenus Cyrtomyrma, like those of Ecophylla, though actively sericiparous in the construction of the nest, no longer spin a pupal envelope.

All the species of Ecophylla and Polyrhachis are confined to the Old World tropics. The third genus, Camponotus, is cosmopolitan and comprises several hundred species, nearly all of which nest in the ground or in dead wood. Only a small number of species and these, so far as known, peculiar to tropical America, build silken nests. Several years ago Goeldi (Forel 1905) observed that the Brazilian $C$. senex employs its larvæ in the construction of a somewhat globular silken nest on trees, and the var. textor Forel of the same ant is known to make a similar nest in Central America. I am able to add a second species, a beautiful little, opaque, red ant, C. (Myrmobrachys) formiciformis Forel, to the list of forms with the same habit. Dec. 28 and 30, 1911, my wife discovered two nests of this ant while we were walking in the neighborhood of Escuintla, Guatemala. One was between two broad liana leaves, which had been converted into an elliptical nest about four inches long and three inches broad by having their edges bound together with a broad film of white silk (Fig. 1). In this nest the silk was quite clean, like that of Ecophylla, i. e., without admixture of any foreign material. The other nest, of about the same size, was of a different appearance. It consisted of silk spun around the radiating petioles of a cluster of pinnate leaves on the branch of a leguminous tree. No leaves were included in the walls of the nest so that very large quantities of silk had to be produced, and this silk was of a gray color and covered with numerous particles of extraneous vegetable matter. Each of the nests contained a flourishing colony of several hundred very active ants, which 
left the nest with their larvæ and pupæ when it was violently shaken. Although I did not see the larvæ in the act of being used as shuttles in the construction of the nest, there can be no doubt that they are thus employed. The pupæ were all enclosed in white cocoons like those of other small species of Camponotus.

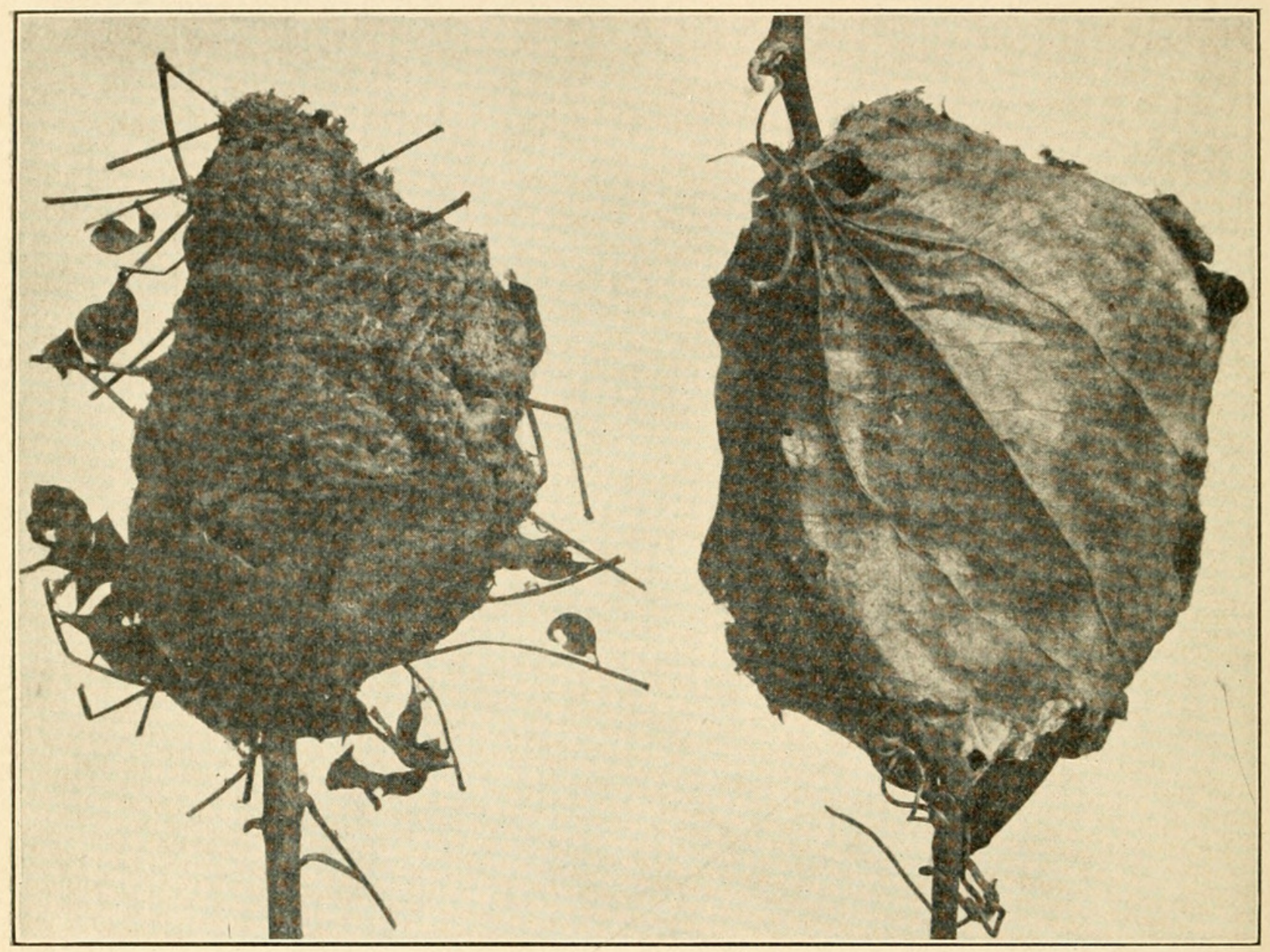

FIGURE 1

Fig. 1. Silken nests of Camponotus (Myrmobrachys) formiciformis from Guatemala, about one-half natural size.

The workers, however, unlike those of nearly all the species of the genus, were monomorphic as in the various species of Ecophylla and Polyrhachis. In C. senex the workers are also practically monomorphic, so that it would seem that the habit of employing the larvæ for spinning the nest tends to make them develop into adults of uniform stature and shape. It is not easy to understand why this should follow. 
Still another inference may be drawn from the presence or absence of cocoons among the various nest-spinning ants. As we have seen, the cocoons are always present, so far as known, in Camponotus, even in the nest-spinning species; in Polyrhachis the cocoon is rarely absent and then only in the species of the subgenus Cyrtomyrma, whereas in Ecophylla it is always absent. Very few species of Camponotus spin nests; a number of species of Polyrhachis have acquired this habit, and all the species of Ecophylla exhibit it in its highest manifestation. This is shown also by the hypertrophic development of the sericteries of young Ecophylla larvæ, as observed Chun (1903) and Karawaiew (1906). Apparently, therefore, in this genus the spinning habit has been shifted back en bloc to an early larval stage and is no longer manifested for cocooning in late larval life; whereas in Camponotus and Polyrhachis (excepting the species of Cyrtomyrma) more mature larvæ are used as shuttles and the cocoon-spinning instincts have not been suppressed.* The employment of the larvæ as instruments for spinning a silken nest in at least three very different genera is only one of several cases of convergent development among ants. While studying the Australian species during the autumn and winter of 1914, I detected another case of an equally adaptive convergence in the coloration of the cocoon. In the great majority of ants the cocoons are white, cream, or pale buff-colored. In some Ponerinæ (Odontomachus, Stigmatomma, etc.) they are brown, but the cocoons of the species to which I refer are dark brown or black. Such cocoons I have found in three very different genera of Ponerinæ, namely, Diacamma, Rhytidoponera sens. str. and Leptogenys (subgenera Lobopelta and Odontopelta), and as nothing has been published on the habits of the species in question, I here subjoin a few of my field notes.

\footnotetext{
*Wasmann (1905), in his rendering of Jacobson's observations on Polyrhachis (Myrma) dives F. Sm., states that one of the larvæ used as a shuttle measured $5 \mathrm{~mm}$. It must, therefore, have been much more nearly full-grown than the larvæ employed by CEcophylla for the same purpose. In this connection reference may be made to Technomyrmex bicolor Emery subsp. textor Forel of Java, which, according to Jacobson (Forel, 1909) inhabits, on the bark of trees, little nests $2 \mathrm{~cm}$. long by $1 \mathrm{~cm}$. in diameter, consisting of silk mixed with vegetable detritus. These nests are described as resembling those of Polyrhachis psena in miniature. If, as Forel remarks, these nests are really the work of the Technomyrmex, we shall have to regard this as a fourth genus which has independently acquired the habit of employing its larvæ in nidification. This would be of considerable interest, because Technomyrmex is a Dolichoderine ant, whereas all the nest-spinning speciesabove mentioned are Componotinæ.
} 
The only species of Diacamma known to occur in Australia is the bronzy black and beautifully sculptured $D$. australe (Fig. 2). The remainder and great majority of the species of the genus are Indomalayan. I found australe rather common in several localities in Queensland (Cairns, Kuranda, Koah, Townsville) nesting in the ground in open, sunny and more or less grassy places. The nests are craters four inches to a foot in diameter and two to six inches high, with a very large central opening, often 1 to $1 \frac{1}{2}$ inches in diameter. This opening leads almost directly into a few large chambers situated

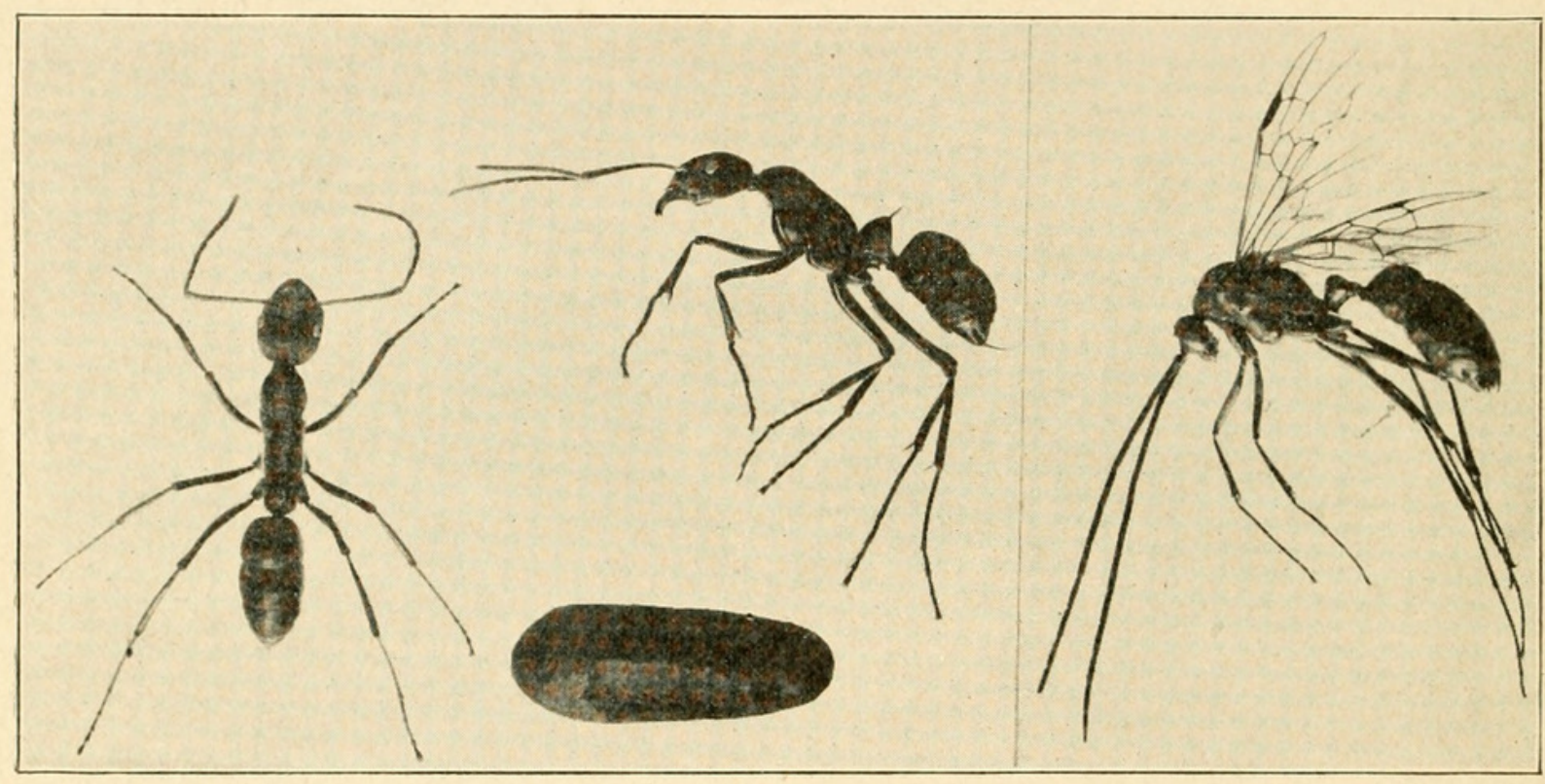

FIGURE 2

Figu RE 3

Fig. 2. Diacamma australe. Workers and cocoon $\times 1 \frac{2}{3}$.

Fig. 3. Diacamma australe. Male $\times 1 \frac{2}{3}$.

in the crater, and from them galleries descend into the ground, apparently to some depth. The outer surface of the crater is often covered with growing grass or other plants. The colony of ants numbers about 50-100 individuals. They are rather timid and usually retreat into the nest at the slightest alarm. Their movements are exquisitely soft and graceful. Their sting is rather feeble, except when it comes in contact with the thin skin on one's wrists or between the fingers. In the "Genera Insectorum" Emery enumerates 13 species of Diacamma and one of these, the Indian D. rugosum, is so well known that 22 varieties and subspecies of it have been described; 
yet no one has ever seen a female Diacamma. In excavating the nests of australe, therefore, I scrutinized the ants very closely in the hope of finding the unknown female, but in vain. Though I searched dozens of nests, I saw nothing resembling a winged or deälated queen or even a worker with conspicuously enlarged gaster. I found plenty of larvæ and pupæ and in some of the nests during late October a number of males. These are bright, reddish yellow, with conspicuously long antennæ, and quite unlike the bronzy black workers. (Fig. 3). As I failed to find any differentiated queen and as all the pupæ were of the same size, I feel confident that in Diacamma the egg-laying function must be usurped by one or more fertile workers during the breeding season.

What impressed me most, while I was excavating the nests of australe, was the very dark brown or black color and tough consistency of the cocoons. I then remembered that I had received very similar cocoons with specimens of $D$. scalpatrum from India and of $D$. cyaniventre from the Philippines. Further study of the nests of australe soon gave a clue to the meaning of this unusually deep pigmentation of the pupal envelope. On the outer surface of two of the craters, which happened to be in shade at the time, I found heaps of cocoons fully exposed to the light. At first I supposed that they were the cocoons of dead or hatched pupæ, but on approaching the nests the wary workers at once carried them into the nest. Then on examining nests exposed to the bright sunlight, I found the cocoons in the superficial chambers so near the large entrance that they could be distinctly seen through it from the outside. Thus while the ants are careful not to place their cocoons in the direct rays of the sun they nevertheless expose them to diffuse daylight. The deeply pigmented cocoon evidently enables the pupa to utilize the heat rays while effectively protecting it from the light and ultra-violet rays. That ants are particularly sensitive to these latter rays has been proved by the experiments of Lubbock (1882), Forel (1886), Forel and Dufour (1902) and Miss Fielde (1904).

It occurred to me that the australe larvæ might spin a white cocoon like other ants and subsequently smear or saturate it with the black meconium, or intestinal contents, which all ant larvæ void just before pupating. But an examination of the cocoons showed this supposition to be erroneous, for the silken 
threads of the cocoon are themselves dark brown and the meconium is deposited in a compact meniscoidal mass within the anal end of the cocoon as in other Ponerinæ and in the Camponotinæ. This differs from the conditions in certain moths (Attacus atlas, Calosamia cynthia, Platysamia cecropia, Saturnia pyri, Eriogaster lanestris) which, according to Batensen, Schawraw, Peterson, Dewitz, Verson and others, are able to adapt the color of their cocoons to that of the objects to which they are attached. In these cases the silk is white or colorless, but is stained by a dark excretory pigment mechanically

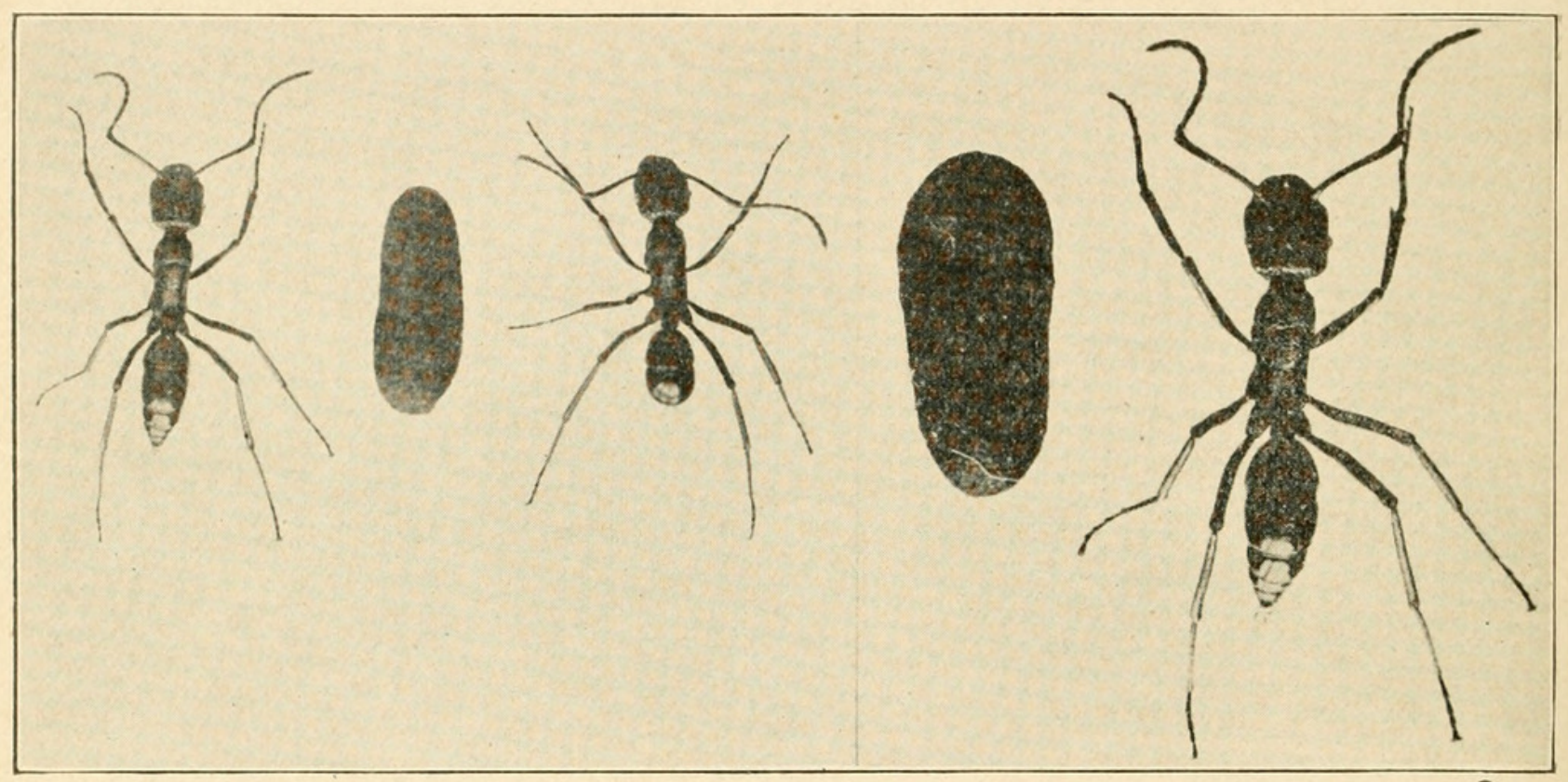

Figu RE 4

FiguRE 5

Fig. 4. Rhytidoponera convexa. Workers and cocoon $\times 1 \frac{2}{3}$.

Fig. 5. Rhytidoponera sp. Worker and cocoon $\mathrm{x}_{3}^{2}$.

applied to the threads as a result of the light stimulus acting directly on the spinning caterpillar. The larva of Diacamma, however, cannot thus be stimulated by the light to spin a darkcolored silk, because the cocoon is completed in the darkness, while the larva lies buried in the earth.

Negro or melanic cocoons, like those of Diacamma, occur also in many if not all species of Rhytidoponera sens. str., (Figs. 4 and 5), a genus largely confined to Australia and New Guinea. The nests of Rh. cristata Mayr, scabra Mayr and convexa Mayr, with the var. rufiventris Forel, are very similar to those of Diacamma australe. They are craters with very large openings, built 
in dry, open, sunny places and containing roomy chambers in which the black cocoons are often visible from outside the nest. I saw many nests of these ants in Queensland, especially in the environs of Brisbane, Townsville and Kuranda. In Kuranda I also found several species of Leptogenys of the subgenera Lobopelta and Odontopelta (conigera Mayr, ebenina Forel, diminuta Forel and its var. yarrabahna Forel and turneri Forel), which had very dark brown cocoons. These ants nest under stones and logs, but they seem to be very restless and one occasionally comes upon colonies moving to new nesting sites. At such times they carry their cocoons concealed underneath their bodies and between their legs and not held out in front as in other ants. It would seem that this concealment of the cocoons under the body is another devise for protecting them from the too direct rays of the sun. In this connection I may say that our single North American species of Lobopelta ( $L$. elongata Buckley of the Gulf States) has brown cocoons, darker than those of our other ants, but paler than those of the Australian species. Other Australian Lobopeltas, such as $L$. mutans, which has small eyes and lives in rotten logs in the dark jungle, have pale brown cocoons. It is also worthy of note that winged females do not exist in Rhytidoponera sens. str. and Leptogenys. In the latter genus the female is wingless and almost exactly like the worker, and the egg-laying function in Rhytidoponera is very probably usurped by fertile workers as in Diacamma. Whether or not this correlation between the presence of black cocoons and the absence of differentiated females is more than a mere coincidence can be decided only by further investigations.

The fact I wish to emphasize is that the larvæ of Diacamma, Rhytidoponera and Leptogenys, while temporarily buried in the soil by their worker nurses, are able to spin cocoons preadapted in color to furthering their own development as pupæ by utilizing the heat of the sun and simultaneously excluding the deleterious light and ultra-violet rays. This utilization, moreover, is possible only through the co-operative agency of other individuals, $i . e$. , the worker nurses of the colony. The natural selectionist will probably insist that the origin of this melanism in an inert and extraneous pupal envelope can be explained only on the assumption of a survival of chance variations in the color of the silk spun by the larvæ. The possible contention of 
the mutationist that a sudden and pronounced deepening of color of the cocoon would be necessary to insure the survival of the pupa will have little force, because even slight differences in color in the direction of greater opacity would be conceivably useful. But no variations would be significant unless the workers developed concomitantly the instinct to expose the cocoons to the heat and light on the surface of the nest. The neovitalist might claim, therefore, that the whole phenomenon is merely another instance of the prospective potency of the colonial psychoid. The modest naturalist who does not habitually abide in this tenuous atmosphere of supreme speculation will be satisfied to regard the melanism of the cocoons as a detail of the larger subject of the coloration of ants in general. As almost nothing has been published on this subject I may be permitted to consider it briefly in these concluding paragraphs.

Adult ants range in color from pale yellow (the primitive color of chitin) through various tones of red and brown to black and, through interference colors superadded to pigmentation, from bronze or æneous, through metallic green, blue and violet to metallic crimson. As here enumerated the shades evidently represent the order of the phylogenetic development of insect coloration generally, as indicated both by the ontogenetic sequence and the comparative study of the various. species and genera. It is not so generally known that both the pigment and interference colors may be shown to depend intimately on the amount of light to which the ants are subjected and therefore on their mode of life.

The primitive, ancestral colors of the Formicidæ were probably red, brown or black, precisely those still prevalent in the majority of species inhabiting temperate regions or the forested portions of the tropics, where the workers, while foraging on the surface of the earth or of the vegetation, are exposed to a moderate insolation. From this condition we can trace three divergent lines of development, each terminating in a peculiar type of coloration, as follows:

1. A number of species have greatly exaggerated the negative phototropism, which is characteristic of most ants, and have therefore taken to a nocturnal or hypogæic mode of life. In all of these forms pigment has been lost, and the workers of the hypogæic species, which never come to the surface of the ground, 
have become pale yellow or pale red or brown. Their eyes have diminished greatly in size or have disappeared. The males and females of these hypogæic forms, however, retain their deep pigmentation and large eyes because they retain the instinct to mate in the sunlight. The principal groups of hypogæic ants which exhibit this retrogressive color-development, at least in the workers, are: Solenopsis, (most species), Machomyrma, Oligomyrmex, Carebara, Tranopelta, Aëromyrma, some species of Pheidole and Crematogaster, the whole tribe Dacetonii, Brachymyrmex and the yellow species of Lasius, i. e., those of the circumpolar subgenus Chthonolasius and of the North American subgenus Acanthomyops, many small Ponerinæ, Enictus, Dorylus, some species of Eciton, Leptanilla, etc.

2. A number of species exhibit a progressive development from red, brown or black to the interference colors. This tendency to what may be called "metallescence" is observable in ants living in very hot, dry, sunny places, and is most pronounced in Australia, where it occurs in the following genera: Chalcoponera (nearly all species), Rhytidoponera (convexa var. violacea Forel), Myrmecia (tarsata F. Sm.), Diacamma, Lobopelta. (some varieties of conigera Mayr), Iridomyrmex (many species, notably detectus F. Sm., discors Forel, bicknelli Forel, cyanea Wheeler, etc.), Leptomyrmex, Camponotus (some species of the subgenus Myrmocamelus), Calomyrmex (splendidus Mayr, purpureus Mayr and an undescribed species from the Cape York Peninsula), Melophorus (aneovirens Lowne and others), and Polyrhachis (hookeri Lowne, schencki Forel and turneri Forel). Some of the most conspicuous and widely distributed Australian ants, such as Iridomyrmex detectus, which is beautifully metallic purple, and other smaller species of the same genus, may be seen running about in the sunlight at a temperature of $115^{\circ}$ to $120^{\circ} \mathrm{F}$, when other ants are hiding in the soil, and in the deserts of Central Australia, where the temperature may rise even higher and the aridity is excessive, the tendency to metallescence is still greater. It is in this region that Calomyrmex splendidus and purpureus and their varieties occur and that I. detectus takes on the pronounced metallic green color of the var. viridiceneus Viehmeyer. The prevalence of interference colors in Australian ants is in marked contrast with their rare and sporadic occurrence in other regions. They occur in 
none of the ants of the temperate zones, with the exception of a species of Forelius (chalybaus Forel) in Argentina and a species of Pheidole (Ph. metallescens Emery) in the Gulf States. Nor does metallescence occur in the ants of the tropics outside of Australia, if we except a few species of Diacamma, Leptogenys and Polyrhachis in the Indomalayan region, a few species of Monomorium and Formica in Mexico and several species of the genus Macromischa which has its center of distribution in the Antilles.

3. A third progressive line of development has led to certain large-eyed tropical ants, in which there is a contrast of black, yellow or red in bands, spots or larger areas involving certain segments or regions of the body. This diversification of color is often secured or enhanced by the development of areas of dense white or golden pubescence or pile, especially on the gaster. The tints are more vivid than in the ants of the first and most primitive category, and seem to indicate that their large-eyed possessors have some slight appreciation of color for its own sake, like the butterflies and many flowerfrequenting flies and beetles. These ants live in open forests and are often very quick in their movements. They comprise such genera as Pseudomyrma in the New World tropics, Opisthopsis and Podomyrma in Australia and New Guinea and the "bull-dog" ants (Myrmecia) of Australia, Tasmania and New. Caledonia. We may also include in this category many tropical species of Camponotus, Polyrhachis and Dolichoderus.

Not only is the coloration of ants thus influenced or determined by light, leat and aridity, but a peculiar adaptation in the investment, or pilosity and pubescence is observed in many species which are subjected to the extremes of these conditions in desert regions. Thus the species of Deromyrma (cockerelli André and albosetosus Mayr), of Pogonomyrmex, Messor and Myrmecocystus, the dominant forms in the deserts of our Southwestern States, are covered with silvery white hairs or pubescence or with both, and in the Sahara similar conditions prevail in Cataglyphis (formerly Myrmecocystus) and Messor. Cataglyphis bombycina, the most extreme of these forms in the development of pubescence, when running over the desert sands in the bright sun-light is said to resemble a drop of quicksilver. Obviously the brilliant white hairs serve to 
reflect the light and heat and thus protect the ants' body from the effects of excessive insolation. Even within the confines of some of our common North American species that have developed local races or varieties, we observe a lack of pubescence in the forms inhabiting moist, shady localities and a great increase in the density of the delicate hairs constituting the pubescence in the xerothermal forms. One example, the common circumpolar Formica fusca, must suffice. The typical form of this ant and its vars. gelida Wheeler, neorufibarbis Emery and subcenescens Emery are found only in rather damp, shady places in the far north or at high elevations, and have very short, feebly developed pubescence, while the much more pubescent vars. neoclara Emery, marcida Wheeler and argentea Wheeler are peculiar to the xerothermal slopes of the Rocky and Sierra Nevada Mountains. In even dryer and warmer localities these forms are replaced by the still more pubescent vars. of $F$. cinerea culminating in the subsp. pilicornis Emery, in which even the eyes are pubescent. Formica fusca var. subsericea, which is intermediate between such forms as the typical fusca and the vars. of cinerea, is the form everywhere common in the Atlantic and Middle States, in open woods and pastures where there is a moderate amount of moisture and sunlight. In Eurasia a very similar series of varieties occurs in similar correspondence with moist, moderate and extremely xerothermal conditions. (F. fusca s. str. and the forms picea, gagates, glebaria and $F$. cinerea with several varieties). Many other examples of this peculiar increase of pubescence and pilosity in ants, with an increase in the aridity and insolation of their habitat might be cited, but a more exhaustive treatment of the subject would consume much time, and, I fear, prove to be rather wearisome to my readers.

\section{BIBLIOGRAPHY.}

1909. Bugnion, Ed-La Fourmi Rouge de Ceylan (Ecophylla smaragdina). Arch. Sci. Phys, et Nat. 1909, pp. 105-107, 3 Figs.

1903. Chun, Carl-Aus den Tiefen des Weltmeeres, Jena, 1903.

1773. Cook, Capt. James-Account of the voyages undertaken by Order of His Present Majesty for Making Discoveries in the Southern Hemisphere, drawn up by John Hawkesworth. Vol. III. London, W. Strahan and T. Cadell, 1773.

1902. Dodd, F. P.-Notes on the Queensland Green Tree Ants (Ecophylla smaragdina?). Victor. Natural. 18, 1902, pp. 136-140.

1905. Doflein, F.-Beobachtungen an den Weberameisen (Ecophylla smaragdina). Biol. Centraeb1. 25, 1905, pp. 497-507, 5 figs. 
1906. Doflein, F.-Ostasienfahrt. Leipzig u. Berlin, Teubner.

1892. Forel, Auguste - Die Nester der Ameisen. Neujahrsblatt d. Zuricher Naturf. Gese11. auf. 1893, (1892),.pp. 479-505, 2 pls.

1896. Forel, Auguste -Ants' Nests. Ann. Rep. Smithson. Inst. 1896, pp. 47-505.

1905. Forel, Auguste -Einige biologische Beobachtungen des Herrn Prof. Dr. E. Goeldi an brasilianischen Ameisen. Biol. Centralbl. 25, 1905, pp. 170-181, 7 Figs.

1909. Forel, Auguste - Ameisen aus Java und Krakatau beobachtet u. gesammelt von Edward Jacobson. 1. Theil. Notes from the Leyden Mus. 31, 1909, pp. 221-253 (ethological part by Jacobson, pp. 233-251).

1911. Forel, Auguste-Ameisen aus Java beobachtet und gesammelt bon Herrn Edward Jacobson. 2. Theil. Notes from the Leyden Mus. 33, 1911, pp. 193-218.

1896. Green, E. E.-On the Habits of the Indian Ant (CEcophylla smaragdina). Trans. Ent. Soc. London. Proc. pp. IX, X, 1896.

1896a. Green, E. E.-(On the Habits of the Indian Ant, Ecophylla smaragdina Fabr.) Abstr. Zoologist, (3), 20, 1896, pp. 110; Ent. Month. Mag. (2) 7, 1896, p. 95 .

1900. Green, E. E.-Note on the Web-spinning Habits of the "Red Ant," Ecophylla smaragdina Journ. Bombay Nat. Hist. Soc. 13, 1900, p. 181.

1903. Green, E. E.-Pupae of the "Red Ant," (Ecophylla smaragdina). Spolia Zeylandica 1, 1903, pp. 73-74, 1 Fig.

1907. Jacobson, Edward-Notes on Web-spinning Ants. Victor. Natural. 24, 1907, pp. 36-38.

1908. Jacobson, Edward-Zur Verfertigung der Gespinnstnester von Polyrhachis bicolor Sm. auf Java. (Communicated by E. Wasmann). Notes of the Leyden Mus. 30, 1908, pp. 63-67, 7 pl.

1906. Karawaiew, V.--Systematisch Biologisches über drie Ameisen aus Buitengorg. Zeitzschr. f. wiss. Insektenbiol. 2, 1906, pp. 369-376, 16 Figs.

1906. Kohl, H. J.-Zur Biologie der Spinnenden Ameisen. Natur u. Offenbarung. 52, 1906, pp. 166-169.

1909. Maxwell-Lefroy, H., and Howlett, F. M.-Indian Insect Life. Calcutta, Simla and London, 1909.

1910. O'Brien, R. A.- - Remarks on the Habits of the Green Tree-Ant of Australia Proc. Zool. Soc. London, 1910 , pp. 669-670.

1906. Reinhardt, Hugo - Weben der Ameisen. Natur und Haus, 15, 1906, pp. 248-249.

1890. Ridley-(On Ecophylla smaragdina) Journ. Straits Branch Roy. Asiat. Soc. Singapore, 1890 , p. 345.

1894. Ridley-(On CEcophylla smaragdina). Trans. Ent. Soc. London, 1894, Proceedings p. XXXIII.

1891. Saville-Kent, W.-The Weaving Properties of the Australian Green Ant. Proc. Roy. Soc. Queensland, 1891.

1897. Saville-Kent, W.- The Naturalist in Australia. London, Chapman and Hall, 1897, 302 pp., 59 pls. 100 text Figs.

1905. Wasmann, E.-Beobachtungen uber Polyrhachis dives auf Java, die ihre Larven zum Spinnen der Nester benutzt. Notes of the Leyden Mus. 25, 1905, pp. 133-140.

1910. Wheeler, W. M.-Ants, Their Structure, Development and Behavior. New York, Columbia Univ. Press. 1910.

1914. Wheeler, W. M.-The Ants of the Baltic Amber. Schrift. phys. ökon. Gesell. Königsberg i. Pr. 1914, pp. 1-142, 66 Figs.

1892. Wroughton, R. C.-Our Ants. Journ. Bombay Nat. Hist. Soc. Part 1, 1892, 48 pp., 2 pls. 


\section{$2 \mathrm{BHL}$ Biodiversity Heritage Library}

Wheeler, William Morton. 1915. "On the Presence and Absence of Cocoons among Ants, the Nest-Spinning Habits of the LarvlE and the Significance of the Black Cocoons among Certain Australian Species." Annals of the Entomological Society of America 8, 323-342.

https://doi.org/10.1093/aesa/8.4.323.

View This Item Online: https://www.biodiversitylibrary.org/item/43631

DOI: https://doi.org/10.1093/aesa/8.4.323

Permalink: https://www.biodiversitylibrary.org/partpdf/193776

\section{Holding Institution}

Smithsonian Libraries

\section{Sponsored by}

Smithsonian

\section{Copyright \& Reuse}

Copyright Status: NOT_IN_COPYRIGHT

This document was created from content at the Biodiversity Heritage Library, the world's largest open access digital library for biodiversity literature and archives. Visit BHL at https://www.biodiversitylibrary.org. 